\title{
Association between Securities and Real Estate Markets: The Case of Ho Chi Minh City
}

\author{
PHAN THI BICH NGUYET \\ University of Economics HCMC - nguyettcdn@ueh.edu.vn \\ PHAM DUONG PHUONG THAO \\ University of Economics HCMC - pdpthao@ueh.edu.vn
}

\section{ARTICLE INFO ABSTRACT}

Article history:

Received:

Nov. 24, 2015

Received in revised form:

May 10, 2016

Accepted:

Sep. 23, 2016

Keywords:

Securities market, real

estate market.
This study inspects the relationship between the securities market and real estate market in Vietnam, particularly the case of Ho Chi Minh City from Q1/2009 through Q3/2014. Using a comprehensive survey of expert opinions, we find that several macro factors including GDP, interest rate, inflation, fiscal policy, monetary policy, securities market regulations, international capital flows, and money market have effects on both the securities and real estate markets, which, in turn, do have mutual interactions. Furthermore, it is suggested by the survey results that among the determinants, policy on foreign investment control has the most powerful impact on capital movements between the two markets. The results of TECM analysis of property price index and VN-Index reveal a bidirectional causality between the two markets, which are positively related in the long run. 


\section{Introduction}

Recent situations in Vietnam reveal the fluctuations experienced by both the securities and real estate markets, changing from the dynamism and strong attraction of investment capital inflows before 2008 to those gloomy days and recession after the global economic crisis. Abnormal movements of the two markets not only draw research attention but also pose the question of whether a relation can be established between the securities market and the real estate one. Indeed, much research has been carried out in the world since 1990, suggesting substantially divided viewpoints. Some studies maintain that no correlation exists between the two markets due to their being affected by various factors and having different impacts on the economy and investment (Schnare \& Struyk, 1976; Goodman, 1978; Geltner, 1990; Wilson \& Okunev, 1996). Others adopt a multidimensional perspective on the two markets' relation: in several countries the securities market is found to relate to the real estate one (Quan \& Titman, 1999; Sutton, 2002), yet this relation is either weak or not in existence (Lin \& Lin, 2011) or is scarcely concluded to be linear/non-linear (Lizieri \& Satchell, 1997; Glascock et al., 2000; Lee $\&$ Chiang, 2004). It is likely that marked differences obtain in these markets of different nations; opposite results are therefore achieved in prior investigations.

The formation and development processes of these two markets in Vietnam have not been long enough; hence, research on their relation is relatively new and unsystematic. Still, regarding foreign experts' experience, in Vietnam in general and in Ho Chi Minh City in particular, they are significantly mutually impacted: growth of this one may give rise to the other, and also risk born in one market may affect the other. For such reasons this paper seeks to define the factors influencing both securities and real estate markets in Ho Chi Minh City between Q1/2009 and Q3/2014, to examine their correlation, and accordingly to propose policy recommendations for managerial solutions and their sustainable development. Qualitative and quantitative analyses are incorporated in conjunction with the use of sample survey technique to address these research objectives.

\section{Theoretical bases}

Securities market, as an essential part of capital market, comes into operation to attract social capital sources to finance businesses, economic institutions, and government agencies for a boost in production volumes, economic growth, or development of various investment projects. On the other hand, real estate market is the 
one for market trading, exchange, lease, mortgage, or transfer of pieces of real estate and the right to use them in accordance with market regulations, and it is the place of concentration of civil real estate transactions in a given locality within a given period of time. Concerning the relationship between securities and real estate markets, conflicting results are perceived with regard to international studies on this topic. Two opposing views that are held either verify or deny the close link between the two markets. Based upon to argue for this association are the following three mechanisms:

\subsection{Cointegrating relationship between securities and real estate markets}

With conclusive empirical evidence, many scholars have reached the concensus about the existing cointegrating relationship between the two markets (i.e. in long terms they are correlated). Some analysts of this school explicate that changes in the real estate market significantly influence the trend of economic activities. In other words, any crisis in the field has a profound impact on production growth, economic prospects, employment, and common household income.

Regarding the securities market, an increase in projected cash flows would bring about increased investment. In terms of the impact of asset ownership, variance in real estate prices causes an alteration to the value of fixed assets on the company's balance sheet; a corresponding change will also be made in corporate capital amounts if these are used by the firm for real estate investments. As a result, the firm's book value will vary, entailing change in the market price of the share. Since the firm's stock price fluctuates according to variance in the price of real estate, there is a cointegrating relation between the securities and real estate markets, as agreed by Liu et al. (1990), Myer et al. (1993), Ambrose et al. (1992), Gyourko and Keim (1992), Lim and Ong (1992), Ling and Naranjo (1999), and Kapopoulos and Siokis (2005).

\subsection{Wealth effect}

To analyze the case of securities and real estate markets, Markowitz (1952), Kapopoulous and Siokis (2005), and Petrova (2010) adopted wealth effect theory, according to which consumption appears as a function of disposable income and total assets. Both the income and aggregate assets have positive effects on levels of consumer expenditure. Total assets are the sum of financial assets (stocks and bonds), real estate, and human assets. Because real estate is deemed not just consumer goods but also a kind 
of investment while the stock is not, households with unanticipated income from stock prices will tend to increase the degree of real estate holdings.

As argued by Kapopoulous and Siokis (2005), the nexus between stock and real estate markets indicates the wealth effect due to the impact of adjustment to investment portfolios. In the event of increased stock prices, there is also a rise in the share of household' portfolios, which are desired to be rebalanced by sale of stocks and purchase of other assets including real estate.

Thus, a pass-through exists from the stock price to real estate price. Higher prices of stock portfolios in the bullish stock market generate optimism, arousing more enjoyment and stimulating additional consumer spending. These psychological conditions do make investors more confident in their assets, loan portfolios, and everything, thus enabling increasing expenditure and future consumption. Consequently, firms enhance their reinvestment in real estate market, which leads to a boost in housing (real estate) demands and eventually in real estate prices.

\subsection{Credit effect}

Coupled with the wealth effect hypothesis is the theory of credit effect, employed by Ghosh et al. (1997), Liow (1999), Seiler et al. (2001), Sim and Chang (2006), and Apergis and Lambrinidis (2011) as a mechanism for explaining the pass-through in the opposite direction from real state market to securities market. A change in real estate value is essential to the outcome of the balance sheet as it alters firm earnings and involves changing stock prices of these firms. Variances in book value result in stock price fluctuations in the stock market (Apergis \& Lambrinidis, 2011).

Sim and Change (2006) exemplified this effect mechanism by reasoning that under the circumstance of higher real estate prices, firms that offer credit loans or are in control of certain pieces of land or houses are likely to gain more benefits. This is because higher asset value allows them to have more mortgages for loans, thus lowering borrowing costs and enabling better access to finance.

Hence, firms oft for more loans and invest in production processes (Kapopoulous \& Siokis, 2005), and their share values, in turn, will be on the increase if one realize the expected return from the outcome of investment. For this reason firms need to hold more real estate assets to cater for extensive investment, which therefore forms a spiral circle of increasing prices on both the markets. 
Petrova (2010) opined that the wealth effect and the credit effect have mutual interaction to create credit cycle effect as illustrated in Figure 1, which also depicts a two-way association between the securities and real estate markets. This mechanism gives an answer to why occurrence of an abnormal shock in the market would be the root of such a persistent impact.

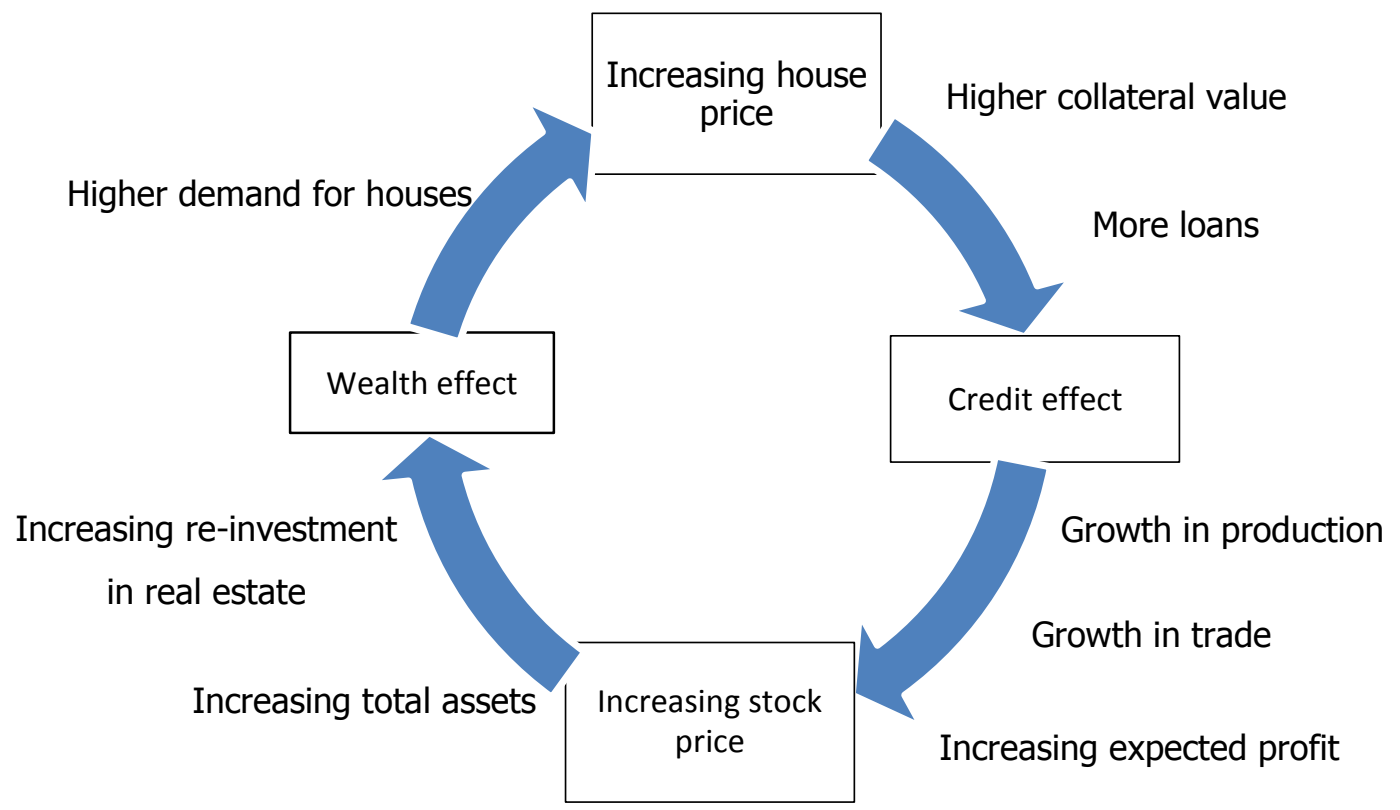

Figure 1. The credit cycle

Source: Petrova (2010)

\section{Empirical evidence of the relationship between securities and real estate markets}

Apart from the theories that clarify the two markets' nexus, a range of empirical studies conducted in different economies produced multiperspective results, which can be summarized as follows:

Two markets independent of each other:

This is confirmed by Schnare and Struyk (1976), Goodman (1978), Geltner (1990), and Wilson and Okunev (1996). 


\section{Linear relation between two markets:}

Empirical studies that adopt this viewpoint are in the majority, including Myer et al. (1993), Gyourko and Keim (1992), Chi (1998), Ling and Naranjo (1999), and Quan and Titman (1999). Both Ibbotson and Siegel (1984) and Hartzell (1986) verified the negative correlation between the American stock and real estate markets during various periods of time, and so did Eichholtz and Hartzell (1996), who studied the ones in Canada, the UK, and the US.

Worzala and Vandell (1993), however, accumulated evidence of the positive association with the quarterly data of the UK's markets. More recent findings were suggested by Sim and Chang (2005) and Kapopoulos and Siokis (2005), and not only was the linear correlation explored in Western countries but its manifestation was also asserted in Asian and developing countries by multiple studies (Stone \& Ziemba, 1993; Ito \& Iwaisako, 1995; Seo \& Kim, 2000; Park \& Park, 2001; Kamada et al., 2007; Zhang $\& \mathrm{Wu}, 2008$; Lin \& Lin, 2011).

\section{Non-linear relation between two markets:}

Liu et al. (1990), Liu and Mei (1992), and Ambrose et al. (1992) showed that real estate indices and common stock price index suggest non-linear impacts. Meanwhile, Lizieri and Satchell (1997), Glascock et al. (2000), and Lee and Chiang (2004) collected evidence of the causal relation between the two markets, which is an obscure mix between linearity and nonlinearity. McMillan (2012) proposed an exponential smooth transition regression (ESTR) approach for modelling the two markets' nexus and argued that investor's behavior might be a cause of a non-linear stock price-house price relationship.

According to Okunev and Wilson (1997), the two markets are two completely separate segments and have no linear correlation. Therefore, they employed a non-linear model for the case of the US markets, the results of which were then compared with those of traditional cointegration tests. While the latter support the argument of no association between the stock and real estate markets, the former are in favor of their partial connection, but due to the fact that their movements are rather low, the divergence between the two may persist. Su (2011) also detected certain nonlinearity when investigating the markets in Belgium, Spain, and France.

Accordingly, analysts of these two markets adopted mainly classical techniques and linear regression models, whereas little has been found so far of the number of studies 
using non-linear models. In Vietnam we find relevant studies on the similar topic, but these mostly address the case of securities market or real estate one in isolation (Nguyen, 2008; Tran \& Nguyen, 2011; Ngo, 2012; Nguyen, 2013); there are very few systematic investigations into the correlation between the two markets.

\section{Methodology}

To illustrate the relationship between these two markets, we have based our study on earlier ones in conjunction with the actual institutions and specifics of the Vietnamese securities and real estate markets for the survey conducted to obtain experts' opinions. According to Kamada et al. (2007), real estate prices would normally be affected by the following factors: (i) basic factors of the economy, such as population and income per capita; (ii) financial factors, such as interest rate and credit limit; (iii) tendency of financial asset prices; (iv) relation between the house price and the spatial factor; and (v) real estate market bubble. The questionnaire was developed, and pilot test was then carried out with a small group of experts. Final survey forms were also sent to the experts in securities and real estate markets.

In addition, we employ econometrical approaches in examining the nature of the two markets' correlation and specify which market affects (are affected by) the other as well as degrees of the impact.

Let VNs be a proxy for the securities market and VNh be a proxy for the real estate market. Data for these two variables are in time series. First of all, it is necessary to check their stationarity. If they are stationary at level, then we consider estimating them using a time series model like VAR. In case they are stationary at first difference, a cointegration test is appropriate since times series, if cointegrated, have long-term relations. ECM, which has been proposed to measure the mutual impacts of time series in the long run, will then be of suitability. In a nutshell, a cointegrating equation shall take the form: $\varepsilon_{\mathrm{t}}=\mathrm{g}\left(\mathrm{y}_{\mathrm{t}}\right)-\mathrm{f}\left(\mathrm{x}_{\mathrm{t}}\right)$.

Also, in testing cointegration most previous studies on the stock or real estate markets commonly applied Engle-Granger or Johansan approaches, depending on hypothesizing the linear relation between two time series and defining $f\left(x_{t}\right)$ as a linear function of $x_{t}$. Nevertheless, Su (2011) and Sargan and Bhargava (1983) pinpointed sharp fluctuations in the operations of both the stock and real estate markets, leading to a non-linear nexus that exists between them. In this research, in order to test the cointegration hypothesis 
we, therefore, inherit the methods of Seo (2006) and Hansen and Seo (2002) while adopting a Granger causality test based on a threshold ECM. For VNs and VNh which are two cointegrated series, an equation that reflects a long-term relationship between $\mathrm{VNh}$ and Vns takes the form:

$\mathrm{VNh}_{\mathrm{t}}=\beta_{1}+\beta_{2} \mathrm{VNs}_{\mathrm{t}}+\mathrm{u}_{\mathrm{t}}$

The equation for measuring short-term adjustment to maintain the long-term relation is:

$$
\begin{aligned}
& \Delta \mathrm{VNh}_{\mathrm{t}}=\alpha_{11}+\alpha_{12} \Delta \mathrm{VNh}_{\mathrm{t}-1}+\alpha_{13} \Delta \mathrm{VNs}_{\mathrm{t}-1}+\gamma_{1} \mathrm{ECT}+\varepsilon_{1 \mathrm{t}} \\
& \text { with ECT }=\mathrm{u}_{\mathrm{t}-1}=\mathrm{VNh}_{\mathrm{t}-1}-\beta_{1}-\beta_{2} \mathrm{VNS}_{\mathrm{t}-1} \\
& \Delta \mathrm{VNs}_{\mathrm{t}}=\alpha_{21}+\alpha_{22} \Delta \mathrm{VNs}_{\mathrm{t}-1}+\alpha_{23} \Delta \mathrm{VNh}_{\mathrm{t}-1}+\gamma_{2} \mathrm{ECT}+\varepsilon_{2 \mathrm{t}}
\end{aligned}
$$

where threshold ECM is adopted for the non-linear relation and $\lambda_{0}$ is the defined threshold level. With ECT $\mathrm{t}-1 \leq \lambda_{0}$ we estimate the correlation coefficient of the ECM, denoted as $\mathrm{ECM}_{1}$. With ECT $\mathrm{t}-1_{1}>\lambda_{0}$ the correlation and coefficient may vary; we estimate another correlation coefficient of the $\mathrm{ECM}$, denoted as $\mathrm{ECM}_{2}$. We conduct the cointegration test, determine non-linear relation of the two variables as well as the threshold, and capture the dynamic adjustment of the two markets in both short and long terms by using $\mathrm{R}$.

\section{Results and discussion}

\subsection{Survey results}

After eliminating the invalid ones, we obtained 217 survey forms. The first part of questionnaire centers on the factors influencing the stock market. A five-point Likert scale was employed. The survey results (Figure 2) suggest that means of such macro factors as GDP, interest rate, inflation, fiscal policy, monetary policy, securities market regulations, international capital flows, money market, and real estate market are all larger than 3, which implies that respondents are agreed on their importance to the securities market. Among them legal regulations, inflation, and interest rate are perceived as significantly impacting on the securities market, which in turn is most powerfully affected by the real estate market (mean of 3.95). Accordingly, the real estate market is found to be one of the key elements to have effects on the securities market in the context of Ho Chi Minh City. 


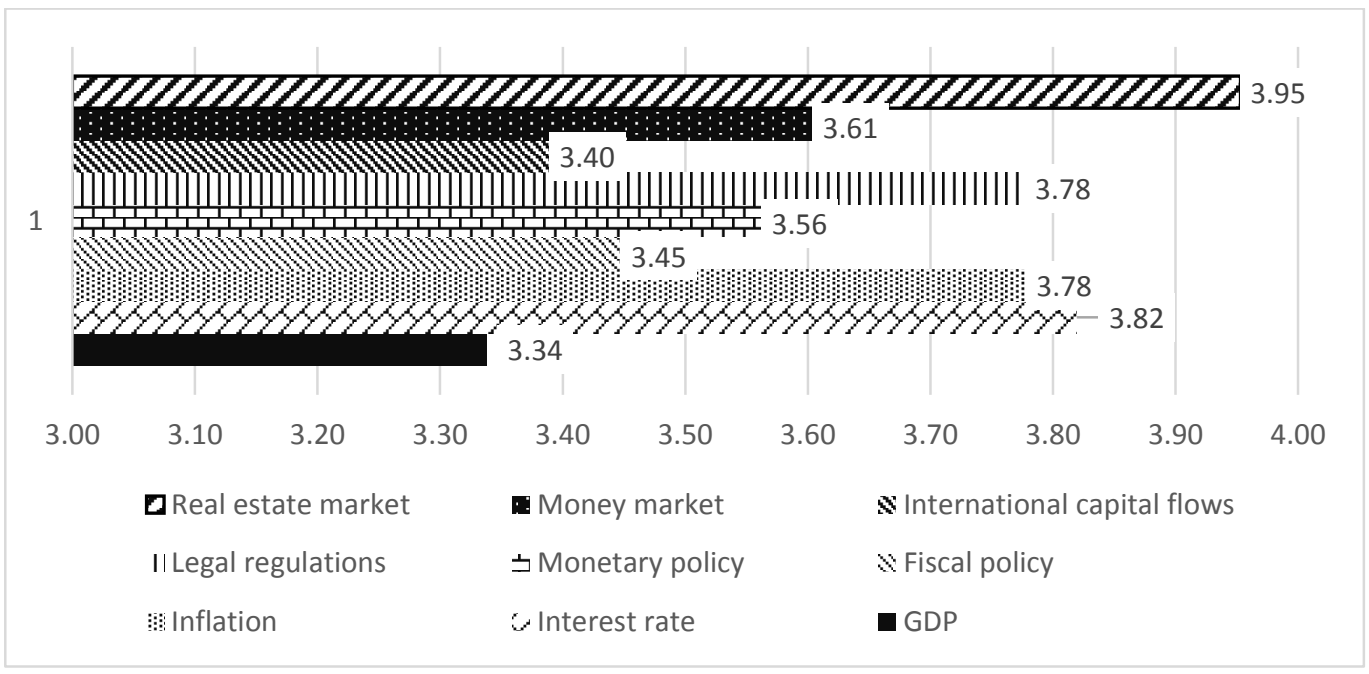

Figure 2. Survey results of factors affecting securities market

In the next section the questionnaire highlights experts' opinions about the macro factors with their effects on real estate market. As indicated in Figure 3, besides the listed factors above, real estate market regulations, information transparency, and securities market are confirmed to have strong impacts on the real estate market. Particularly, rather significant effects are exerted by interest rate, inflation, and the securities market (mean of 3.73). This implies that a bidirectional causality exists between these two markets.

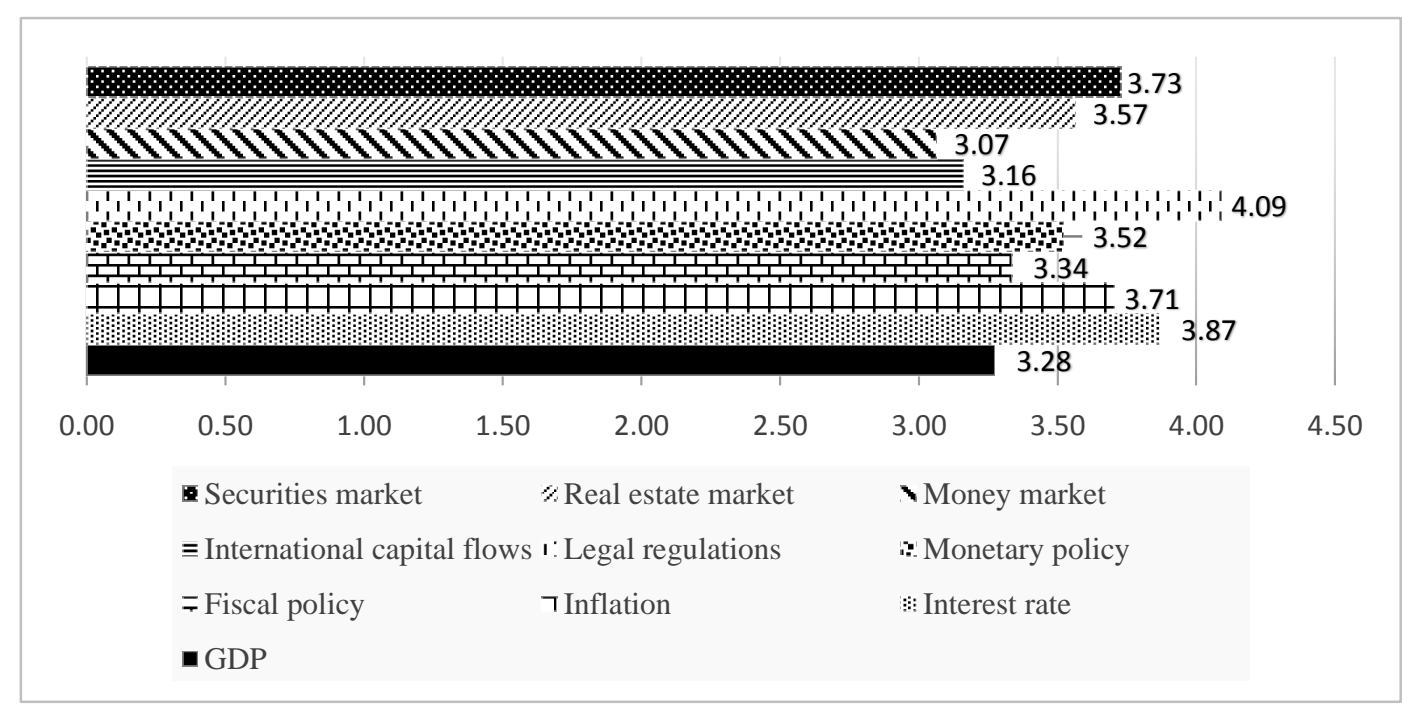

Figure 3. Survey results of factors affecting real estate market 
Furthermore, the questionnaire refers to the nature of the relationship between the securities and real estate markets. As shown, most survey participants affirm the existence of their connection. Only $2 \%$ of the respondents find absolutely no relationship between the two markets, while as many as $36 \%$ and $51 \%$ approve their fairly close and rather close connection respectively. The questions become more specific as with the use of a fivepoint scale, ranging from 1 (totally disagree) to 5 (totally agree). Given the causal relationship, the mean score for verifying the impact of the securities market on the other is 2.9 , whereas in the opposite direction it is 3.3. To a notable extent the highest mean reaches 4.09 for the perspective that their relation is not static yet changes over time.

The final section emphasizes the determinants of capital movements between the securities and real estate markets. The highest mean is 3.6, reflecting the agreement about regulations on restrictions on foreign investment. Next comes the factors relating to anti money laundering with its mean of 3.52 and liquidity of the real estate market, which is believed to have effect on the capital movement, with the average level of agreement of 3.3. It is thought that in the context of the Vietnamese markets the idea of foreign investment control that has the most significant impact on capital movements seems quite logical, as evidenced by the recent change in the policies on foreign investment in the stocks and real estate.

\subsection{Empirical results}

We employ the Savills Property Price Index in Ho Chi Minh City from Q1/2009 to Q3/201 and the VN-Index collated from Ho Chi Minh City Stock Exchange (HOSE) for the same period with the use of daily averages from the quarterly data. Having collected the data, we perform interpolation to obtain monthly indices and an increased number of observations in order to analyze the impact of the two markets' adjustment when exceeding the threshold. Thus, the final sample for analyses consists of 69 observations for the two variables VNh and VNs.

\section{Table 1}

Descriptive statistics

\begin{tabular}{lccccc}
\hline Variable & Obs. & Mean & Std. dev. & Min & Max \\
\hline VNh & 69 & 94.95436 & 5.266945 & 88.61822 & 105.5312 \\
VNs & 69 & 467.7198 & 73.92495 & 266.9537 & 658.4428 \\
\hline
\end{tabular}


The 2006-2007 period could be considered a hot growth phase for Vietnam's securities market, and its participants derived a high rate of profit from their speculative activities. This created a large surplus fund that flowed to the property market and resulted in the abnormal growth of high-level segment and thereby the inevitable bursting of the real estate bubble in 2008. Our selection, therefore, is made of the 20092014 period as a research phase when the property price index exhibited its downward trend over time. Although VN-Index recorded its lowest level in 2009, it was, by the end of this year, assessed by the analysts as recovering by 57\%, compared to end-2008, but as decreasing by $46.28 \%$, compared to early-2008; this proves that little by little the stock market has become more stable in addition to its gradual recovery after the crisis.

\section{Tests for cointegration and the nature of two markets' relation}

The results of stationarity test show that VNh and VNs are stationary at first difference. Therefore, we continue with cointegration test and check the threshold's existence using the test developed by Seo (2006) with the null hypothesis that there is no cointegration among the series and the first hypothesis that there exists cointegration with the threshold.

\section{Table 2}

Test results using Seo's (2006) technique

\begin{tabular}{lccc}
\hline Test statistic & 11.79477 & p-value (20 bootstrap) & 0.0000 \\
\hline Critical values (bootstrap): & & & \\
$90 \%$ & $95 \%$ & $97.5 \%$ & $99 \%$ \\
11.79477 & 11.79477 & 11.79477 & 11.79477 \\
\hline
\end{tabular}

At all significance levels, the test statistic is 11.79477 , equal to critical values with pvalue ( 20 bootstrap) equal to zero. Thus, the null hypothesis can be rejected, implying that VNh and VNs are cointegrated and two markets are associated in long terms.

Additionally, we conduct another test in accordance with Hansen and Seo's (2002) technique with the null hypothesis that there is a linear relation and the first hypothesis that there exists cointegration with the threshold. 


\section{Table 3}

Test results using Hansen and Seo's (2002) technique

\begin{tabular}{|c|c|c|}
\hline Test statistic & 14.59342 & 0.02 \\
\hline \multicolumn{3}{|c|}{ Critical values (bootstrap): } \\
\hline $90 \%$ & $95 \%$ & $99 \%$ \\
\hline 11.62832 & 12.45044 & 15.1585 \\
\hline
\end{tabular}

At $1 \%$ significance level, the test statistic is less than critical values; thus, we reject the null hypothesis, which means that the relation between VNh and VNs is not a linear one, and accept the first hypothesis, which means that VNh and VNs cointegrate with the threshold.

Accordingly, the test results using both Seo's (2006) and Hansen and Seo's (2002) methods suggest that the two series that proxy for two markets demonstrate a non-linear relationship between them at $99 \%$ confidence level.

\section{Long-term correlation between securities and real estate markets}

The estimated results from TVECM model show that there is a long-term relation between two markets:

$$
\mathrm{VNh}_{\mathrm{t}}=\text { constant }+0.198394 \mathrm{VNs}_{\mathrm{t}}+\mathrm{u}_{\mathrm{t}}
$$

The regression coefficient in the above equation indicate that two markets have a positive correlation in the long run. When the VN-Index increases by one point, the property index increases by 0.198394 , and a decrease in the former's point also leads to that in the latter's.

As shown by the results, the data sample can be divided into three regions, reflecting the change in the nexus between two markets in short terms with two threshold values:

$$
\lambda_{0}=-9.716601 \text { and } \lambda_{0}=-7.503655
$$

In the event of real estate market volatility, a short-run stock market adjustment is required to their long-term relation that exists. An ECM equation estimates the adjustment speed to maintain this association. The coefficient of ECT will show the direction and adjustment speed in case of disequilibrium in the previous term to return to equilibrium in long terms. The two values of $\lambda_{0}$ divide the data series into three regions as below:

With ECT $<-9.716601$ 
ECM equations:

$\Delta \mathrm{VNh}_{\mathrm{t}}=0.0035+1.6162 \Delta \mathrm{VNh}_{\mathrm{t}-1}+0.0027 \Delta \mathrm{VNs}_{\mathrm{t}-1}+0.0061 \mathrm{ECT}+\varepsilon_{1 \mathrm{t}}$

$\Delta \mathrm{VNs}_{\mathrm{t}}=39.9731+0.5589 \Delta \mathrm{VNs}_{\mathrm{t}-1}-160.7356 \Delta \mathrm{VNh}_{\mathrm{t}-1}+0.7012 \mathrm{ECT}+\varepsilon_{2 \mathrm{t}}$ $(2 \mathrm{a}) * * *$

With $-9.716601<E C T<-7.503655$

ECM equations:

$\Delta \mathrm{VNh}_{\mathrm{t}}=-0.7665+0.7111 \Delta \mathrm{VNh}_{\mathrm{t}-1}+0.0066 \Delta \mathrm{VNs}_{\mathrm{t}-1}-0.0858 \mathrm{ECT}+\varepsilon_{1 \mathrm{t}}(1 \mathrm{~b})$

$\Delta \mathrm{VNs}_{\mathrm{t}}=37.8701+0.2340 \Delta \mathrm{VNS}_{\mathrm{t}-1}-6.5334 \Delta \mathrm{VNh}_{\mathrm{t}-1}+4.4339 \mathrm{ECT}+\varepsilon_{2 \mathrm{t}}$

With ECT > -7.503655

ECM equations:

$\Delta \mathrm{VNh}_{\mathrm{t}}=-0.2849+0.6600 \Delta \mathrm{VNh}_{\mathrm{t}-1}+0.0006 \Delta \mathrm{VNs}_{\mathrm{t}-1}+0.0288 \mathrm{ECT}+\varepsilon_{1 \mathrm{t}}$ (1c) $* * *$

$\Delta \mathrm{VNs}_{\mathrm{t}}=-5.6575+0.8125 \Delta \mathrm{VNs}_{\mathrm{t}-1}+0.2915 \Delta \mathrm{VNh}_{\mathrm{t}-1}+0.7974 \mathrm{ECT}+\varepsilon_{2 \mathrm{t}} \quad(2 \mathrm{c})^{* * *}$

Equation (1a) shows that when the securities market is volatile, the real estate one represents its downward adjustment to restore equilibrium to fit the other in long terms. Similarly in Equation (2a), the adjustment speed of the securities market drops during real estate market volatility, and the speed should be faster as compared to that of the real estate market. In this region the coefficients in Equation (2a) are significant at $99 \%$ confidence level. Since there is a non-linear relation between the two markets, their volatilities and correlation will vary when the ECT exceeds the threshold.

Given Equation (1b), a volatility in the securities market occurs when the real estate one is lower than the equilibrium level, so its upward adjustment is very likely toward a long-term equilibrium relationship with the securities market. Meanwhile, Equation (2b) indicates the tendency for the securities market to decrease adjustment speed under the circumstance of real estate market volatility. Moreover, decreasing adjustment speed of the securities market is greater than the increasing speed of the other, which is consistent with Fu et al.'s (1997) argument that for each change in the macro economy, the stock market volatility is expected to occur earlier and stronger than volatility in the real estate market.

Equations (1c) and (2c) suggest that when there is disequilibrium in the previous term, it is the causality that caused downward adjustment in both the securities and real 
estate markets to restore long-run equilibrium. This downward adjustment in the securities market is not rapid in comparison with that in the other regions, but it is faster than that in the real estate market. Particularly, this region accounts for $71.6 \%$ of the observations in the sample (i.e. the period from early-2013 to 2014), and most of the coefficients in these two equations are statistically significant at $99 \%$ confidence level.

To sum up, the estimated results confirm the positive long-run correlation between the securities and real estate markets, and the securities market is found to have decisive influence on the other. Their non-linear causality which exists in short terms has led to certain adjustment toward a long-run equilibrium relation. The findings of econometric approach are in line with our analyses of the real estate and securities markets for the typical case of Ho Chi Minh City, and also with previous findings of Worzala and Vandell (1993) and Petrova (2010).

\section{Conclusion and policy implications}

As indicated by the results attained from both econometric and survey approaches, there is a two-way relation between Vietnam's securities and real estate markets that reflect their positive long-run association where the securities market has a decisive impact on the other. Furthermore, from the survey findings, the macro factors such as GDP, interest rate, inflation, fiscal policy, monetary policy, stock market regulations, international capital flows, and money market have effects on the two markets, and policy on foreign investment control, particularly, exerts the most powerful impact on capital movements between them. Also, by using a TECM approach a cointegrating relation is found to exist between the securities and real estate market. On the basis of the above analyses, we propose the following implications:

Regarding the securities market, the legal framework should be completed synchronously for its operations while economic corridors and an open environment need to be created to attract a greater surge of foreign investment interest. Management of the country's securities market should be in accordance with international norms that ensure the openness and transparency of listed institutions and adequate legitimate rights of investors in the spirit of Securities Act. Necessary practices should also include enhancing control over the activities of intermediary organizations, reducing too much intervention in securities market operations, minimizing its dependence on the banking system, improving the role of capital markets in the economy, encouraging professional 
and long-term investments in the stock market, and creating optimal conditions for the presence of long-term funds in the market. Others involve implementing the schemes on restructuring and development of securities exchanges, securities firms, depository systems, and securities clearing, and improving the operational capacity of financial intermediaries.

Regarding the real estate market, it is important to improve the system of legal documents on investment, land, construction, and real estate trading and formulate a uniform legal basis for stable market development and convenient real estate transactions. The Government should implement its role in market monitoring by using laws and mediate effective real estate market operations as representatives of land owners through the regulation of the market supply concerning primary land use rights and the flexible use of tax policies. There is a need to restructure the market and develop diverse real estate product types, especially houses that fit the needs and affordability of each residential group in the society. Solving the problem of supply-demand deviation in housing development, attracting FDI in the real estate market, and making efficient use of FDI capital sources are essential in addition to establishing a close link with unification between this market and others, notably the securities market.

In the context of Ho Chi Minh City, earlier issuance of basic information with regard to the real estate market is needed for in-depth analysis of supply and demand sources with sufficient statistics on every segment of the market, which thus helps visualize the market development process. Provisions of real estate prices should be planned in harmony with the regulations on land value and others on market competition as well as supply and demand. The monitoring role of the city's authorities should be strengthened in effectively exploiting or using land resources, controlling land supply for the primary market through allocation, leases, and changes in land use purposes, and actively regulating real estate prices through pricing, taxing, and charging mechanisms in association with real estate transactions.

A mutual interaction has been verified in this research between the two markets, and this is crucial to their participants, who always require necessary instruments to identify and/or assess their status via various information channels for investment decisions. A fluctuation in this market may be interpreted as a signal for the other to be forecast and vice versa. Therefore, it is imperative to improve the organizational patterns of the markets and competence of market actors, especially real estate firms, brokers, and 
valuation and trading agencies, which facilitates their healthy and professional operations

\section{References}

Ambrose, B. W., Ancel, E., \& Griffiths, M. D. (1992). The fractal structure of real estate investment trust returns: A search for evidence of market segmentation and nonlinear dependency. Real Estate Economics, 20(1), 25-54.

Apergis, N., \& Lambrinidis, L. (2011). More evidence on the relationship between the stock and the real estate market. Journal of Economic Literature, No. 85, September/October 2011.

Chi, H. J. (1998). Circulative relation of stock, bond, real estate markets to business cycle. Korean Management Review, 27(5), 1277-1296.

Eichholtz, P., \& Hartzell, D. (1996). Property shares, appraisals and the stock market: An international perspective. The Journal of Real Estate Finance and Economics, 12(2), 163-178.

Geltner, D. (1990). Return risk and cash flow with long term riskless leases in commercial real estate. Real Estate Economics, 18(4), 377-402.

Ghosh, C., Guttery, R. S., \& Sirmans, C. F. (1997). The effects of the real estate crisis on institutional stock prices. Real Estate Economics, 25(4), 591-614.

Glascock, J., Lu, C., \& So, R. (2000). Further evidence on the integration of REIT, bond and stock returns. The Journal of Real Estate Finance \& Economics, 20(2), 177-194.

Goodman, A. C. (1978). Hedonic prices, price indices and housing markets. Journal of Urban Economics, 5(4), 471-484.

Gyourko, J., \& Keim, D. (1992). What does the stock market tell us about real returns? Journal of the American Real Estate Finance and Urban Economics Association, 20(3), 457-486.

Hansen, B. E., \& Seo, B. (2002). Testing for two-regime threshold cointegration in vector errorcorrection models. Journal of Econometrics, 110(2), 293-318.

Hartzell, D. (1986). Real estate in the portfolio. In F. J. Fabozzi (Ed.), The institutional investor: Focus on investment management. MA: Ballinger.

Ibbotson, R., \& Siegel, L. (1984). Real estate returns: A comparison with other investments. Real Estate Economics, 12(3), 219-242.

Ito, T., \& Iwaisako, T. (1995). Explaining asset bubbles in Japan. NBER Working Paper No. 5350. Retrieved from http://www.nber.org/papers/w5350

Kamada, K., Hirata, W., \& Hajime, W. (2007). Determination of land-price movements in Japan. Bank of Japan Working Paper Series 2007. Retrieved from https://www.boj.or.jp/en/ research/wps_rev/wps_2007/wp07e07.htm/ 
Kapopoulos, P., \& Siokis, F. (2005). Stock and real estate prices in Greece: Wealth vs. credit price effect. Applied Economics Letters, 12(2), 125-128.

Lee, M. L., \& Chiang, K. (2004). Substitutability between equity REITs and mortgage REITs. Journal of Real Estate Research, 26(1), 96-113.

Lim, J., \& Ong, G. (1992). Real estate in an emerging financial market: The Singapore experience. Paper presented at the 1992 AREUEA International Conference on Real Estate and Urban Economics, Redondo Beach, CA (October).

Lin, T. C., \& Lin, Z.-H. (2011). Are stock and real estate markets integrated? An empirical study of six Asian economies. Pacific-Basin Finance Journal, 19(5), 571-585.

Ling, D. C., \& Naranjo, A. (1999). The integration of commercial real estate markets and stock markets. Real Estate Economics, 27(3), 483-515.

Liow, K. H. (1999). Corporate investment and ownership in real estate in Singapore: Some empirical evidence. Journal of Corporate Real Estate, 1(4), 329-342.

Liu, C. H., \& Mei, J. (1992). The predictability of returns on equity REIT's and their comovements with other assets. Journal of Real Estate Finance and Economics, 5(4), 401-418.

Liu, C. H., Hartzell, D. J., Greig, W., \& Grissom, T. V. (1990). The integration of the real estate market and the stock market: Some preliminary evidence. Journal of Real Estate Finance, 3(3), 261-282.

Lizieri, C., \& Satchell, S. (1997). Interactions between property and equity markets: An investigation of the linkages in the United Kingdom (1972-1992). Journal of Real Estate Finance and Economics, 15(1), 11-26.

Markowitz, H. (1952). Portfolio selection. Journal of Finance, 7(1), 77-91.

McMillan, D. (2012). Long-run stock price-house price relation: Evidence from an ESTR model. Economics Bulletin, 32(2), 1737-1746.

Myer, F. C. N., \& Webb, J. R. (1992). Return properties of equity REITS, common stocks, and commercial real estate: A comparison. The Journal of Real Estate Research, 8(1), 87-106.

Ngo, X. T. (2010). Investigating the relationship between financial markets and real estate market (in Vietnamese). IEF Research Papers. Hanoi, Vietnam: Institute of Economics and Finance.

Nguyen, H. H. (2013). Analyzing the relation between stock market development and economic growth in Vietnam (in Vietnamese). Journal of Economic Development, No. 271, 23-35.

Nguyen, N. V. (2008). Policy factors affecting urban house prices: The case of Vietnam (in Vietnamese). Journal of Economic Development, No. 254, 24-29.

Okunev, J., \& Wilson, P. (1997). Using nonlinear tests to examine integration between real estate and stock markets. Real Estate Economics, 25(3), 487-503.

Park, H. J., \& Park, C. (2001). A study on the forecasting in land market using time series model. Housing Studies, 9(1), 27-52. 
Petrova, T. (2010). What are the effects of housing prices and the REIT index in Bulgaria on the Bulgarian stock exchange index? The Park Place Economist, 18(1), 41-47.

Quan, D., \& Titman, S. (1999). Do real estate prices and stock prices move together? An international analysis. Real Estate Economics, 27(2), 183-207.

Sargan, J. D., \& Bhargava, A. (1983). Maximum likelihood estimation of regression models with first order moving average errors when the root lies on the unit circle. Econometrica, 51(3), 799-820.

Schnare, A., \& Struyk, R. (1976). Segmentation in urban housing markets. Journal of Urban Economics, 3(2), 146-166.

Seiler, M., Chatrath, A., \& Webb, J. (2001). Real asset ownership and the risk and return to stockholders. Journal of Real Estate Research, 22(5), 200-212.

Sim, S.-H., \& Chang, B.-K. (2006). Stock and real estate markets in Korea: Wealth or credit-price effect. Journal of Economic Research, 11(2006), 99-122.

Stone, D., \& Ziemba, W. (1993). Land and stock prices. Journal of Economic Perspectives, 7(3), 149-166.

Su, C.-W. (2011). Non-linear causality between the stock and real estate markets of Western European countries: Evidence from rank tests. Economic Modelling, 28(3), 845-851.

Sud, S. H., \& Kim, K. S. (2000). An empirical study on the behavioral changes in real estate prices. Journal of Korean Housing Association, 8(1), 5-26.

Sutton, G. D. (2002). Explaining changes in house prices. BIS Quarterly Review, September, 46-55.

Tran, T. V., \& Nguyen, T. G. (2011). An application of Hedonic model on studying determinants of real estate prices in Ho Chi Minh City (in Vietnamese). Journal of Economic Development, No. 254, 18-23.

Wilson, P., Okunev, J., \& Ta, G. (1996). Are real estate and securities markets integrated? Some Australian evidence. Journal of Property Valuation \& Investment, 14(5), 7-24.

Worzala, E., \& Vandell, K. D. (1995). International direct real estate investments as alternative portfolio assets for institutional investors: An evaluation. Paper presented at the IRES/ERES meetings. Stockholm, Sweden.

Zhang, Y. L., \& Wu, J. (2008). Study on periodical correlation between real estate market and stock market in China. Chinese Real Estate, 1, 29-31. 